\title{
COMPARISON OF RISK IDENTIFICATION AND ASSESSMENT METHODS IN PROJECTS
}

\author{
HANNA SOROKA-POTRZEBNA
}

University of Szczecin, Faculty of Management and Economics of Services, POLAND

e-mail: hanna.soroka@wzieu.pl

\begin{tabular}{l|l}
$\begin{array}{l}\text { RECEIVED } \\
\text { JECEPTED }\end{array}$ & $\begin{array}{l}18 \text { January } 2018 \\
\text { 2 September } 2018\end{array}$ \\
CLASSIFICATION & D81, G32, O22 \\
KEYWORDS & $\begin{array}{l}\text { risk, project, management, risk management methods } \\
\text { Project realization is always connected with a relatively high risk. Project managers try to identify and assess } \\
\text { possibly all types of risks to which a particular project is exposed. For this purpose, different methods of iden- } \\
\text { tification and risk assessment in projects are used. The selection of the appropriate method or methods guar- } \\
\text { antees the introduction of an appropriate strategy that will allow reducing the negative effects of risk or even } \\
\text { preventing certain events that would have a negative impact on the project. This article show the analysis of the } \\
\text { literature on the subject to compare different methods of the risk identification and assessment in projects. } \\
\text { It also try to answer the question is there one universal method and if not, what should it include. }\end{array}$
\end{tabular}

\section{Introduction}

Risk identification and assessment have an important role in many areas of business activity of enterprises, especially during project realization. In the literature there are many definitions of risk. T.T. Kaczmarek defines it as the possibility of failure, and in particular the occurrence of events beyond the control of the acting subject, which he cannot accurately predict and which cannot fully prevent, and which - by reducing the useful results and/or by 
increasing expenditures - receive action entirely or partly attribute effectiveness and economic viability (Kaczmarek, 2005 , p. 27). From the point of view of the risk in projects, the risk is an uncertain event or circumstance which, if it occurs, may have a positive or negative impact on at least one of the project's objectives, such as scope, time, cost or quality (PMI, 2013, p. 309). Project risk is also defined as the probability of occurrence of a phenomenon or activity that may have positive or negative effects on the course of the whole project and/or its individual parts (European Commission, 2004, p. 145).

Risk management is a process of undertaking risk-related activities by organization and achieving an acceptable level of that risk. Risk management process consists four basic stages (Wysocki, 2013, pp. 125-134):

1. Risk identification - defining the risk to which the project is exposed as well as relations occurring between individual risks.

2. Risk analysis - qualitative and quantitative (determining quantifiable values of the probability value and the effects of unfavorable events both for individual project activities and for the entire undertaking) (Skorupska, Kuchta, Górski, 2012, p. 61).

3. Risk control - planning activities aimed at minimizing the identified risk.

4. Risk monitoring - monitoring and controlling changing risk factors in the project.

In the field of project management, risk management involves identifying specific threats to the project system and determining actions aimed to eliminate these risks or minimize the impact of them on the project.

\section{Litepgture review}

Project risk management should include both qualitative and quantitative analysis to determine the impact of risks on costs, deadlines or technical specifications of the project. Such assessment allows to distinguish the threats recognizable at the beginning of the project and those that cannot be identified. Moreover, it allows to recognize those threats that have an impact on the course of the project and, therefore, must be constantly monitored.

Analysis is extremely difficult, so it is very important to select proper methods for identification and risk assessment. The level of threats in the project is determined by three basic parameters: the probability of their occurrence, the severity of their consequences and their detection. In practice, the assessment results from the joint use of the first two. Unfortunately, sometimes a series of events, seemingly without negative consequences for the project - it becomes a contribution to its failure.

In general, the risk classification methods can be divided into two groups (Monkiewicz, Gassiorkiewicz, 2010, p. 41). First, qualification methods are descriptive, supported by calculations of the basic project parameters: time, cost and description of their impact on the final shape of the project. Second, enumeration methods are based mainly on statistical methods.

The literature presents various methods of project risk assessment and classification, the first of which is the PERT method. It serves to assess of the progress of project work. This method can be divided into two phases, the first one refers to the calculation of the level of activities, the second refers to the level of the project. The PERT method is a set of mathematical equations called Rangego-Kutta, which by using times: optimistic, probable and pessimistic, allow to calculate the probabilities of side effects (Trocki, Hrucza, Ogonek, 2003, p. 196).

The PERT method focuses on the critical path - the longest way to implement the project. The use of this method makes it possible to identify activities to which special attention should be paid as well as places on 
the schedule, where the slowdown takes place. Detection of delays allows to reduce the time allocated for the implementation of the project (Kerzner, 2005, pp. 180-184).

The concentration of the PERT method mainly on time problems is of great importance in obtaining accurate, real time schedules. The disadvantage of the PERT method is that strict control of time often causes not putting attention on other important issues related to the project. In addition, the use of this method, as a result, does not give a list of threats, does not assess the probability of their occurrence, but only indicates tasks that delay could delay the project (Jędrych, Pietras, Szczepańczyk, 2012, pp. 67-68).

Another method is Monte Carlo simulations, that allows to effectively detect financial and time risks for individual activities as well as the entire project. On the basis of data, the risk can be determined by means of the probability of project implementation within specified costs and time. Method involves determining relative risk levels, which is served by different, distributions: monotonous, normal, triangular and beta distributions (Pritchard, 2002, p. 267).

Monte Carlo simulations require the use of a computer, because it uses a random number generator to count the uncertainties of individual components of the hierarchical work structure. Then, for each of the structural elements, a critical path is determined, and for the entire project duration and estimated cost. This process is repeated many times, and the result of each loop is called an experiment. Individual experiments constitute a distribution. This method is most often used to calculate the probability of completing a project successfully, at a given budget and at a specific time (Wittek, 2006, pp. 422-423).

The advantage of next method is speed and form, which does not require giving opinions. Crowford's method is most often used in situations where the project requires more employees to solve the problem, but they do not have to make decisions. This method is based on the collection of risk data, which allows problem formulation (www.4pmp.pl). Then the problem is repeatedly analyzed by the respondents who write down their observations. Repeatability of the process allows, over time, to get an answer to the question about what constitutes the greatest threat and how to react to it. The effectiveness of this method depends on a clearly defined question, which is big disadvantage.

Another methodology of risk identification and assessment is Value at Risk, which allows to calculate the probability of investment loss based on the analysis of three components - time, level of certainty and amount of loss. VaR allows to calculate the maximum expected investment loss in the given time. Value at risk depends on two parameters: time horizon and confidence level (tolerance). Measuring Value at Risk allows to get an answer to the question, what is the maximum potential loss that a company can incur with a given probability within a certain time from an investment of a certain value. This loss can be determined on the basis of statistical analyzes, so the distribution of probabilities of behavior of a given security. The risk is estimated in three steps (Kuziak, 2003, pp. 29-30):

- measurement - using the algorithm calculating loss,

- model - application of mathematical theory and logic,

- verification - interpretation of measurement results.

The method most often used after contact with threats, in order to avoid similar risks in the future is risk modeling. This method is based on creating a list of questions enabling risk assessment for project activities. The questions should relate to the activities of the organization and indicate the scope of risk that the organization is able to bear (Altman, 1998, pp. 1724-1725). The steps of creating the risk model are (Pritchard, 2002, pp. 215-225): 
- identification of the most important threats and opportunities,

- assigning weights to the indicated factors,

- determining the scale and methods of the estimated probability,

- developing measures for estimating probabilities,

- determination of the range of numerical results,

- graphical presentation of results,

- model testing.

The advantage of this method is its high accuracy and usability. Risk modeling is a method that allows to make a decision to start or stop a project.

The probability-effect method is a method in which level of the threat depends on its impact on the project. One of the following ways of operation is used here:

1. By reading the global assessment, corresponding to the consequences for the project.

2. By assigning an assessment in an intuitive way to each of the project's risks. The sum of the partial grades will be an assessment of the entire project.

3. By providing an approximate effects for each of the project's objectives. These estimates will determine the overall significance of the effects of threats on each of the project's assumptions, as well as on the global value.

The assessment of the severity of the threat is sometimes based on quantitative estimates coming from analysis or simulation, as well as from empirical estimations derived from experience gained from working on other projects - transferred by a parametric model or by analogies. Although this method of risk assessment is more difficult to implement, it is certainly worth paying attention to both project managers and project team members because the assessments obtained in this way have an undeniable advantage over numerical ratings.

Another method is risk sheets, that allows to look separately at the severity of the threat, the probability of its occurrence and possible damage that it may cause in the project. This method does not fully reflect the scale of the risk to which it is exposed (International Organization for Standardization, Space Systems Risk Management, ISO 17666).

A good solution is to multiply the estimated weight of the project by the probability of its occurrence, thanks to which the degree of risk is obtained. By comparing the severity of all identified threats in one table the project's risk profile is obtained. Taking into account the need of minimize the threats, the risk sheet should be supplemented with proposals to minimize identified risks, along with the estimated cost of their introduction.

Expert evaluations is a method which aim is to identify threats, assess risks or estimate data necessary to apply enumerated risk assessment methods. Successful interviews require meeting several basic rules. The interviewer must understand the area of competence in which the interlocutor turns, should ask open questions, allowing free conversations of the interlocutor and should avoid confronting the interlocutor. The interviews must be clearly defined and should be conducted in an environment that will not distract the interlocutor. Time of the interview should be controlled.(Jędrych, Pietras, Szczepańczyk, 2012, pp. 100-101) This method allows identification of risk based on the opinions of independent experts. However, it does not bring knowledge about the future, but only expectations of a group of specialists. 
The aim of the article is to compare different methods used to risk identification and assessment in the project, and try to point the best one. To achieve this goal, the methods were compare from the point of purpose, important feature and versatility.

\section{Method}

The research is based on the analysis of literature that is related to the subject of project management. The comparison includes the analysis of several selected methods used for risk identification and assessment in the projects. Comparison of methods allows to answer the question is there one universal method for enterprises to identify and analyze the risk.

\section{Results}

The analysis of the risk identification and assessment methods presented above allows dividing them into two groups. First are the concepts used to identify hazards and determine delays, such as PERT, Crawford's method or risk sheets and VaR. The second group includes methods for risk analysis only, such as Monte Carlo simulations, probability-effect method, expert assessments and risk modeling. The collective comparison is presented in Table 1.

Table 1. Comparison of the risk identification and assessment

\begin{tabular}{|c|c|c|c|}
\hline Method & What is used for? & Important feature & Versatility \\
\hline PERT & $\begin{array}{l}\text { - risk identification and analysis, } \\
\text { - determination of delays in the } \\
\text { project }\end{array}$ & $\begin{array}{l}\text { Determination of the } \\
\text { critical path }\end{array}$ & $\begin{array}{l}\text { Critical path is an element that is in every project. There are } \\
\text { always tasks which failure to complete or extend may result in } \\
\text { failure of the project }\end{array}$ \\
\hline $\begin{array}{l}\text { Monte Carlo } \\
\text { simulations }\end{array}$ & risk analysis & $\begin{array}{l}\text { The element } \\
\text { of probability }\end{array}$ & $\begin{array}{l}\text { Each project is based on the probability of occurrence } \\
\text { of specific events that may adversely affect the implementation } \\
\text { of the project }\end{array}$ \\
\hline Crawford method & $\begin{array}{l}\text { - risk identification, } \\
\text { - determination of delays in the } \\
\text { project } \\
\text { - assessment of possible losses } \\
\text { and ways to respond to risk }\end{array}$ & $\begin{array}{l}\text { Assessment of the } \\
\text { competence of the } \\
\text { project team }\end{array}$ & $\begin{array}{l}\text { Employees' competences have an impact on the closure the } \\
\text { project with success, so their evaluation is a key element of any } \\
\text { project }\end{array}$ \\
\hline Value at Risk & assessment of possible losses & Assessment of losses & $\begin{array}{l}\text { The assessment of losses has a great importance when } \\
\text { deciding whether or not to start a project }\end{array}$ \\
\hline Risk modeling & risk analysis & $\begin{array}{l}\text { Evaluation of the } \\
\text { organization }\end{array}$ & $\begin{array}{l}\text { Assessing the organization in terms of market position, } \\
\text { development, technology, allows to identify threats to the } \\
\text { project implementation successfully }\end{array}$ \\
\hline $\begin{array}{l}\text { The probability-effect } \\
\text { method }\end{array}$ & risk analysis & Risk weight rating & $\begin{array}{l}\text { Assessment based on quantitative estimates as well as } \\
\text { empirical estimates have an advantage over numerical ratings }\end{array}$ \\
\hline Risk sheets & $\begin{array}{l}\text { - risk analysis } \\
\text { - probability of occurrence } \\
\text { of risk } \\
\text { - assessment of possible losses }\end{array}$ & Project risk profile & $\begin{array}{l}\text { Multiply the estimated weight of the project by the probability } \\
\text { of its occurrence, the degree of risk is obtained }\end{array}$ \\
\hline Expert evaluations & risk analysis & Experts' opinions & Risk analysis based on the opinions of independent experts \\
\hline
\end{tabular}

Source: own elaboration.

The discussed methods find their application in various phases of risk management. Depending on the type of project, the advancement of work, available resources, experience in the implementation of work, you can apply a different methodology that will probably contribute to the success of the project. The diversity of methods allows 
to choose a method adequate to the needs of a given undertaking. The data presented in Table 1, however, do not allow to point out one universal method. The question then arises whether it is possible to create one method that can be used in every phase and in every project?

Due to the importance of the impact of risk on the implementation of projects, it is worth trying to create a universal method of risk management. The universal method should combine key features of the discussed methods of risk identification and assessment in projects. This is due to the fact that so far no universal method has been developed, but each of them finds its application in relation to different types and aspects of projects.

The universal method should be based on elements that distinguish the methods used so far. Such a method should determine the critical path, risk profile, probability elements, as well as include the assessment of both the organization itself, employee competences, losses, as well as the severity of threats. The combination of these elements in one method, extended with the opinion of experts in line with the specification of the organization's activities, can be a universal method for identifying and assessing risk in projects.

\section{Limitations}

Due to the limited volume of the article, it covers only a few selected methods discussed in the literature.

\section{Conclusions}

Many methods of identifying and assessing risk are described in the literature, so it is a great difficulty for people implementing the project to choose the right one. Usually the known and popular methods are used, not those that would actually meet the needs of a particular project.

Therefore, it is extremely useful to compare methods in terms of their suitability and emphasize differences. It helps people managing the project to obtain information about the method that is most useful for a project implemented by them.

The article presents the results of the comparison of the methods of risk identification and assessment. Interesting from the point of view of theoretical and practical considerations, it may be creating a universal method that would combine the features of the analyzed methods.

\section{References}

Altman, E.I., Saunders, A. (1998). Credit risk measurement: Development over the last 20 years. Journal of Banking and Finance, 21, 1721-1742.

European Commission (2004). Project Cycle Management Guidelines. Brussels.

Jędrych, E., Pietras, P., Szczepańczyk, M. (2012). Zarządzanie projektami. Łódź: Uniwersytet Technologiczny w Łodzi.

Kaczmarek, T.T., Zarzycki, M. (2005). Poradnik eksportera. Bydgoszcz-Warszawa: Oficyna Wydawnicza Branta.

Kerzner, H. (2005). Advanced Project Management Edycja Polska. Gliwice: Helion.

Kuziak, K. (2003). Koncepcja wartości zagrożonej VaR. Warszawa: Statsoft Polska.

Monkiewicz, M., Gąsiorkiewicz, L. (2010). Zarządzanie ryzykiem działalności organizacji. Warszawa: C.H. Beck.

PMI (2013). A Guide to the Project Management Body of Knowledge. Pennsylvania: PMBOK@.

Pritchard, C.L. (2002). Zarządzanie ryzykiem w projektach - Teoria i praktyka. Warszawa: Wig Press.

Skorupka, D., Kuchta, D., Górski, M. (2012). Zarządzanie ryzykiem w projekcie. Wrocław: Wyższa Szkoła Oficerska Wojsk Lądowych im. T. Kościuszki. 
Trocki, M., Hrucza, B., Ogonek, K. (2003). Zarządzanie projektami. Warszawa: PWE.

Wittek, J. (2006). Zastosowanie metody Monte Carlo w zarządzaniu ryzykiem. Zeszyty Naukowe. Organizacja i Zarządzanie, 34, 421-435.

www.4pmp.pl/zarzadzanie-ryzykiem/metoda-crawforda.

Wysocki, R.K. (2013). Efektywne zarządzanie projektami. Tradycyjne, zwinne, ekstremalne. Gliwice: Helion.

Cite this anticle aS: Soroka-Potrzebna, H. (2018). Comparison of risk identification and assessment methods in projects. European Journal of Service Management, 3 (27/2), 395-401. DOI: 10.18276/ejsm.2018.27/2-48. 